\title{
THE INFRA-CAMBRIAN BIORADIATION EVENT: A REVIEW FROM THE PERSPECTIVE OF THE YANGTZE PLATE IN SOUTH CHINA AND CORRELATION WITH COEVAL STRATA IN BRAZIL
}

\author{
BERND-DIETRICHERDTMANN \\ Institute of Applied Geosciences, Technical University Berlin, Ernst-Reuter-Platz 1, D-10587 Berlin, Germany. \\ berni.erdt@tu-berlin.de
}

\begin{abstract}
Analytical work by a Sino-German team of paleobiologists, sedimentologists and geochemists during the past 3 years on numerous sections representing multifacies sparsely to moderately fossiliferous Terminal Proterozoic to lowermost Cambrian platformal to deeper water sediments on the South China Plate revealed that the entire ca. 57 Ma postglacial interval between the Varanger "Snowball Earth" glaciation (600 $\mathrm{Ma}$ ) and the first record of biomineralization during the earliest Cambrian (543 Ma) on the Yangtze Platform documents significant biological signals. The fossil (including trace fossil) record represents testing grounds for heterotrophic organisms, some having been mobile, others not, some having revealed only embryonic stages, altogether justifying an inclusion of these fossils as metazoans (bilateran and other body plans). In exceptional cases preservational windows resulting from different ultra finegrained lithologies permit insights into original body plans of soft-body forms. Moreover, bacterially controlled pre- to early diagenetic phosphatization, which is widespread during the Terminal Neoproterozoic, coated both minute skeletal and soft-tissue structures and delivered fossil "embryos" and larval stages in great abundance and diversity from rocks dating back to ca. $580 \mathrm{Ma}$. The intra-South China Plate geological and paleobiological disposition and their correlations and implications for the interpretation of coeval occurrences, especially with the Corumbá (central-west of Brazil) and Arroyo del Soldado (Uruguay) depositional and fossil record, are outlined and discussed.
\end{abstract}

Key words: Terminal Proterozoic-Early Cambrian bioradiation event, China, Brazil.

RESUMO - Apresentam-se aqui dados de numerosas seções compreendendo várias fácies pouco a moderadamente fossilíferas, ocorrentes em depósitos marinhos plataformais até de águas profundas na plataforma continental do Sul da China, com distribuição estratigráfica entre o Proterozóico Superior e o Cambriano Inferior. Este estudo revelou que a totalidade do intervalo pós-glacial de aproximadamente $57 \mathrm{Ma}$, entre a glaciação do Varangiano ("Varanger Snowball Earth", $600 \mathrm{Ma}$ ) e o primeiro registro de biomineralização durante o início do Eocambriano (543 Ma) na plataforma de Yangtze, documenta sinais biológicos significantes. O registro fóssil, incluindo icnofósseis, apresentou níveis com ocorrência de organismos heterotróficos, alguns móveis, outros não, justificando sua inclusão no grupo dos metazoários (bilatérios e outros). Casos excepcionais de preservação em diferentes litologias permitem associar as impressões a partes moles de organismos ou, mais comumente, à fosfatização por bactérias eodiagenéticas, que estiveram dispersas durante o final do Neoproterozóico, revestindo ao mesmo tempo estruturas esqueletais e partes moles. Também foram encontrados "embriões" fósseis e estágios larvais em grande abundância e diversidade em rochas com idades anteriores a aproximadamente $580 \mathrm{Ma}$. A disposição geológica e paleobiológica na plataforma continental do Sul da China e suas correlações e implicações para a interpretação de ocorrências síncronas, especialmente com o registro fóssil e deposicional do Grupo Corumbá (SW Brasil) e Arroyo Del Soldado (Uruguai) são apresentadas e discutidas.

Palavras-chaves: Evento de biorradiação do Proterozóico Terminal-Eocambriano, China, Brasil.

\section{INTRODUCTION}

Prerequisite to the search for the "oldest" fossils as markers for the earliest evolution of metazoan life is an undisturbed record of shallow marine deposition beginning with Varangerian diamictites (of the so called "Snowball Earth" glaciation) and passing into undisputable Cambrian sediments. Charles Darwin who wondered about the "apparently spontaneous" appearance of fossils at the base of the Cambrian did not have such a sedimentary succession at his disposal in the mid $19^{\text {th }}$ century, not anywhere in the British Isles, nor could he command of the body of knowledge about regional geology on a global scale as we enjoy today. Even much later, in the 1950s, Preston Cloud or Dolph Seilacher (according to Brasier, 1979), who probably coined the term "Cambrian Explosion" to describe the phenomenon of the quasi spontaneous appearance of most of the extant phyla in fossilized form, could fully secure such a transitional 
sedimentary record for a database. More recently, biologists have approached this problem of first bilateran metazoans by applying molecular biological concepts of DNA sequencing, however, the initial calculations resulted in a vast time span difference of ca. $600 \mathrm{Ma}$ from the calculated first hypothetical diversification of "slimy" metazoans to the first appearance of either trace fossils or first biologically (enzymatically) constructed "edifices" (shells or skeletons) made by multicellular animals.

Although fossil evidence may not be tantamount to the prior existence of non-skeletonized bilateral life forms, the discoveries of soft-bodied preservation in rocks older than the late Atdabanian Chengjiang Lagerstätte in China (Steiner et al., 1993) and the appearance of trace fossils as evidence of motility in middle to late Ediacaran (Terminal Neoproterozoic) sediments (Weber \& Zhu, 2003) renders the molecular biologists' ${ }^{\prime}$ claims to date the cradle of metazoan life as far back as to more than 1 billion years, rather doubtful. One has to take the fact into consideration that within the Ediacaran successions in China (and elsewhere) ultra fine- grained lithologies similar to those of the Yuánshan Formation at Chengjiang do occur - but not having yielded any metazoan-like fossils at all.

Transitional geological records across the latest Precambrian to earliest Cambrian interval are now known from many parts of the world, especially from the multi-facies basin to platform sequences of the South China Plate, but also from other parts of the world. Due to the enormous regional extent (within at least 10 provinces of China; see Figure 1) of well preserved sedimentary rocks representing various deep to very shallow marine lithofacies of this stratigraphical interval, a Sino-German team of paleobiologists, sedimentologists, stratigraphers and geochemists began a research project in 1999 to investigate as many sections as possible in China and looking for both fossil evidence and for the paleoenvironmental aspects which may be related to the emergence of metazoans and their intial processes of biomineralization. The present paper is, however, to be considered a progress report which also intends to illuminate the discoveries made in Brazil and Uruguay and includes this author's personal

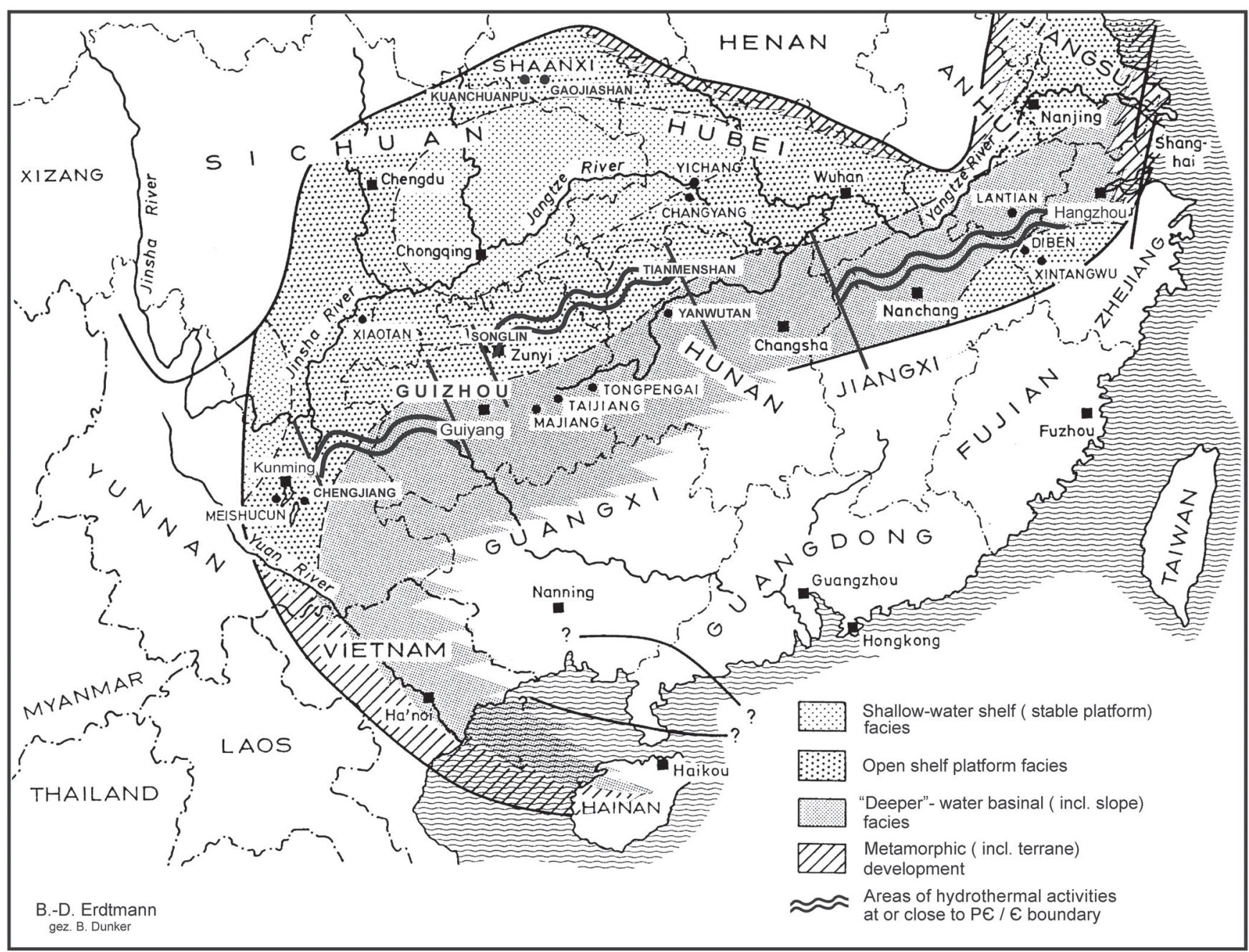

Figure 1. Outline of the South China Plate and the principal facies developments during the Late Neoproterozoic to Early Cambrian time. Capitals of provinces are indicated by black squares and investigated section localities by black circles. The connecting wavy lines are hypothetical volcanogenic lineaments indicating positions of locations where hydrothermal ores have been found (adapted from Steiner et al. 2001, Fig. 1). Locations of regional subfacies "highs" and "lows" (local islands and basins) could not be fitted into the scale of this map because their individual geographic extent and distribution are only vaguely known to date. 
observations made during a short inspection visit of relevant sections in the Corumbá region during July 2003.

\section{THE GEOLOGICAL SETTING IN CHINA AND SOUTH AMERICA}

The South China Plate owes its current configuration to a long history of tectonic events. The oldest verifiable event was probably connected with the Grenvillian assemblage of Rodinia as observed by the Sibao deformation and metamorphism at ca. $960 \mathrm{Ma}$. At this time, the Mesoproterozoic Lengjiaxi Group was deformed by compressional tectonism and unconformably overlain by the volcaniclastic Banxi Group. In the regions of central and southern Hunan, and in southern Guizhou and adjacent Yunnan, the ca. 750 Ma Cryogenian (Neoproterozoic II) Liantuo Group disconformably overlies Banxi rocks, displaying rifting which is assigned to the Chengjiang or Xuefeng Movement, this probably having been related to the earliest break-up movements of Rodinia. At most places, especially around the then forming Yangtze Platform in northern Hunan, Hubei, Sichuan and southern Shaanxi (Figure 1), the coarsely arkosic Liantuo Group is slightly disconformably overlain by ca. $600 \mathrm{Ma}$ diamictic Nantuo continental and marine tillites and tilloids. These deposits are now referred to the recently introduced Nanhua System (All-China Committee of Stratigraphy, 2001) reflecting the "Snowball Earth" or the latest Varangerian worldwide glaciation (ca. 750 - 600 Ma). These diamictites, although heterogeneous (depending on local sources for the erratics), form the base of all measured sections in the South China region by the infra-Cambrian Sino-German bioradiation project, which support data on this paper. The Nantuo or equivalent tillites are encountered practically everywhere and these are capped by a decimetric to metric tepee-structured dolomite, the so-called "Cap Dolomite" which was probably a direct product of rapid ultra-greenhouse warming and marine transgression (Schrag et al., 1999).

The subsequent infra-Cambrian Sinian (Terminal Proterozoic or Neoproterozoic III or Ediacaran, according to Knoll, 2003) System is developed in greatly varying facies depending on either platform (Yangtze Platform), slumped slope (Jiangnan) or basinal (Zhujiang) settings, with a few special regional and local subfacies. These deposits may indicate regional island arc and rift-related upwarping developments throughout the ca. 57 Ma history of Sinian epeirogenetic tectonism on the South China Plate (Figure 1). Another phase of faulting, submarine hydrothermal venting and outright ashfalls can now be pinpointed to have taken place during the earliest Cambrian Meishucunian Stage (the pre-trilobitic Small Shelly Fossil, for short "SSF", or possibly Nemakit-Daldynian? stage), especially within the Jiangnan Slope and throughout the Zhujiang basinal regions (Figure 1). These extensional movements, the so-called "Sancha Disturbance" (Erdtmann \& Steiner, 2001), may be a late reaction to the world-wide fragmentation of Rodinia or of the short-lived megaplate Pannotia (Powell et al., 1993; Powell, 1995) and may also be a regional response to the multiple hot-spot induced upwarping connected with the Cadomian (in South America: "Brasiliano" or "Paraguayan" of Alvarenga et al., 2000) Orogeny. This biostratigraphically and regionally pinpointed tectonic event is evidenced by sulfidic ores and PGE-enriched hydrothermal vent fields along several fault-bounded settings stretching from western Guizhou to eastern Zhejiang over a linear distance of ca. $1.600 \mathrm{~km}$ (Figure 1; see also Steiner et al., 2001, fig. 1). Along these vent fields (including collapsed smokers?) the very earliest non-biomineralized sponges and bivalve arthropods, hydrozoans and a few other early but unequivocal metazoans (Niutitang Biota) were found (Steiner et al., 2001), but most of these are not yet described (Zhao et al., 1999).

In the Pantanal and Uruguayan successions deposition obviously ceased near the very end of the Terminal Neoproterozoic, but on and marginal to the South China Plate there is a continuous Cambro-Silurian record of sedimentation which more clearly delineated the general litho- and biofacies realms during the Cambrian and Ordovician times. Upon deposition of a kilometric succession of Cambro-Silurian and younger Paleozoic rocks on the South China Block, faulting and deformational (and only minor metamorphic) tectonism took place only within certain areas (especially along the plate margins) during the Variscan and Indo-Sinian orogenies.

\section{THE SINIAN-LOWER CAMBRIAN FOSSIL RECORD IN SOUTH CHINA}

Due to multi-facies lithogenetic environments during the Sinian-Cambrian interval, the South China Plate, and especially the Yangtze Block region of its northern subplate, offers ideal testing grounds to investigate the biological responses to the incumbent physical changes. Although depositional hiati are most common for the Sinian and Lower Cambrian in the carbonate dominated Yangtze Platform, fairly continuous depositional records are observed along its peripheral belts and the Jiangnan slopes, as well as along former island arc margins and around local volcanic islands and atolls or other uplift structures. Continuous deposition is also characteristic for the basinal Zhujiang facies, but due to depth-related condensation and predominant anoxia and volcanigenic chertification, the fossil record of this area during the critical interval is rather poor. For example, during the transitional Meishucunian (e.g. Nemakit-Daldynian?) stage, rich records of "Small Shelly Fossils" (SSF) - with decreasing representation bathymetrically down-slope - are preserved only in the shallow marine infralittoral shelves of the central Yunnan region (Chengjiang, Haikou and Meishucun around Dianchi Lake). In the same way, there is a basinward increase of organic matter contents related to primary productivity, but except for some long-ranging acritarchs, no diverse fauna or palynomorphs appear - so far - in the deeper water Sinian to Lower Cambrian sediments. Exceptions, however, exist and these are observed along uplifted structural highs, such as in the Kaiyang-Weng'an Uplift of central Guizhou, where phosphoritic beds are common throughout the Sinian. From specific strata occurring 
along these axial structures, the first so-called "embryos", possibly reflecting both earliest metazoan pre-larval stages (Bengtson \& Yue, 1997; Zhang Yun et al., 1998; Xiao et al., 1998) or, alternatively, algal affinities (Xue et al., 1999) were reported and critically discussed (Conway Morris, 1998b).

More promising and productive concerning the search for potential fossils would be the carbonate-dominated platformal region of northern Hunan and adjacent Hubei, the traditional type area for the Sinian System along the scenic Three Gorges of the Yangtze River, between Yichang and Zigui. Resulting from the current construction of the Yangtze High Dam, excellent new road sections were recently made available in this area. The partially carbonate, partially fineclastic Dengying Formation presents an Upper Sinian preservational template for the presence of biotic remains and for large-bodied fossil tracks documenting macrobiotic motility, which usually, but not exclusively, indicates metazoan activities. The Shibantan Member of the middle part of the Dengying Formation has yielded both diverse types of trace fossils and mass occurrences of remains of the composite gliding bacteria Vendotaenia in strata, documenting vacillating depositional environments with regard to dysaerobic and anaerobic conditions (Steiner, pers. comm. 1997). At similar stratigraphic levels, but along the northern platform margin at Kuanchuanpu, in southern Shaanxi, excellent examples of the tubular ringed-cone Cloudinia and Conotubus, and the older fully compressed Shaanxilithes and 3-D preserved Gaojiashania (both may not have been body-fossils but mucus-lined burrows?) have been observed and described from Dengying beds (Bengtson \& Yue, 1992, Hua et al., 2000a). Future field studies are intended to investigate more discrete facies developments within the carbonate platformal areas and along their periphery. Already now, it is possible to ascertain significant intra-platformal depositional depressions (such as microbasins in which the Yangjiahe phosphoritic mudstones and black shales were formed south and southwest of the Huangling Anticline in the Three Gorges region of Hubei) yielding informative fossil records bridging the dysaerobic facies of the earliest Meishucunian stage.

For the same stratigraphic top Neoproterozoic to basal Cambrian interval, but representing a well oxygenated carbonate facies along the northern periphery of the Yangtze Platform, the ca. $55 \mathrm{~m}$ thick Kuanchuanpu Formation, which overlies disconformably the dolomitized Dengying Formation, yielded massive occurrences of SSF and various larval stages of phosphatized metazoan embryos with great details of their intracellular ultrastructures (Yue \& Bengtson, 1999). It is now possible to state - applying a new branch of science, the Paleoembryology - that these truly basal Cambrian embryos represent cnidarians, prosobranch molluscs and probably early arthropods, worms and echinoderms. This, once again, proves that at the very base of the Cambrian, not only highly diverse but also very advanced protostomian and deuterostomian bilateran metazoans must have existed. This is also supported by a rather diverse trace fossil record which includes Didymaulichnus (molluscan trail, generally occurring in assemblages "Cruziana ichnofacies"), Bergaueria, Gordia, Torrowangea and Palaeophycus and which characterize the Upper Phosphate Beds (Member) of the Meishucunian Zhujiaqing Formation (Weber \& Zhu, 2003).

Virtually, everywhere within the South China Plate, regardless of bathymetry and lithofacies, Meishucunian strata are usually disconformably covered by the Niutitang black shales (late Tommotian?-Early Atdabanian?). In some areas, rich sulfidic ores and very extreme stable isotope and REE excursions are observed; subjacent to this disconformable contact, Dengying limestone breccias occur (hydrothermal cracking?) and ore-filled vertical fault systems die out in the subsequent black shales (e.g., at Sansha, NW Hunan, Erdtmann \& Steiner, 2001). At these localities, the ore formation and REE excursions are attributed to hydrothermal activities (Steiner et al., 2001). Although the black shales of the Niutitang Formation are called by different names (Hetang Formation in Zhejiang; Guojiaba Formation in southern Shaanxi; Xiaoyangxi Formation in parts of Hunan; Shiyantou Formation in Yunnan), they are present everywhere (Figure 2). In the Jiangnan (paleo-slope) and partly also in the Zhujiang (paleo-basin) regions, the basal part of these anaerobic black shales exhibits strong internal prediagenetical slumping documenting possible seismic shocks and thigmotactic foundering prior to enduration. In the shelf area around Kunming and Chengjiang in central Yunnan, the coeval Shiyantou black shales are only a few meters thick and display enormous Diplichnites, Psammichnites and Palaeophycus showing possibly an aerobic environment above the substrate-water interface, but in most other places, especially in central Guizhou (Zunyi-Songlin: Zhao et al., 1999) and at Sancha in NW Hunan, where hydrothermal vents reach the base of the black shales, mass occurrences of organic-shelled bivalved arthropods (Perspicaris), sponge tufts and complete bodies of articulated hexactenellid sponges are quite common (Steiner et al., 1993; Mehl \& Erdtmann, 1994; Steiner et al., 2001). The first trilobites, such as eodiscoids (Zunyidiscus), bradoriids (Kunmingella, etc.), and then Naraoia and Scenella, as well as very large sponge spicules appear within the higher beds of the Niutitang black shales (Zhao et al., 1999) and slightly higher upsection within the black shale sequence. In Yunnan, at the now classic localities near Chengjiang, Haikou and Meishucun, the upper black shales are replaced by the greenish to ochre weathering Yuanshan Formation, which in the upper part harbours the spectacular and greatly diverse soft- and hard-body so-called Chengjiang Fauna.

\section{ACOMPARISON WITH COEVAL RECORDS FROM OTHER PARTS OF THE WORLD}

Although post-“Snowball” (Varanger) Neoproterozoic sedimentary sequences are well-known from virtually all of today's continents, the Yangtze Platform sequences are unique due to their multi-facies development including rich primary phosphorite deposits (Shields et al., 2000), carbonates 


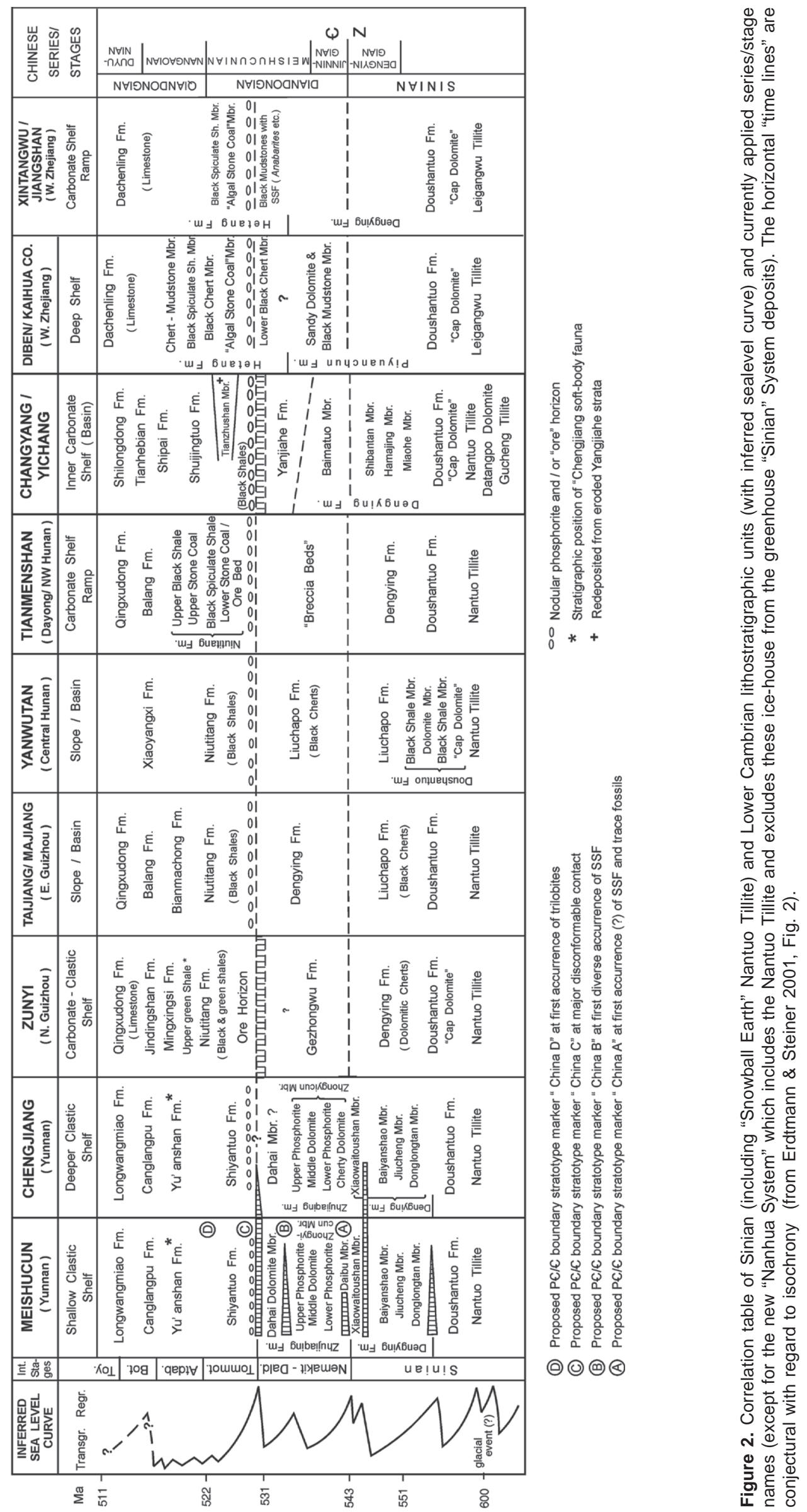


at various stratigraphic levels, black shales, low temperature overprint and greatly individualized chemical and biological records. Most remarkable, however, is the distinct absence (so far!) of Ediacaran "vendobionts" with the exception of a single specimen of Paracharnia discovered from a dislocated "float rock" in the Yangtze River and reported by Sun (1986) from the Dengying Formation of the Three Gorges region of Hubei. The occurrences of Ediacara-type fossils (Vendobionta) are extremely dependent on well oxygenated highenergy sandy or silty facies of nearshore environments apparently of a specific type, which has not yet been encountered on the Yangtze Plate during the latest Proterozoic stratigraphic interval. It may also be possible that this specific arenaceous-type environment, which is also typical of the Wonoka Siltstone and Rawnsley Quartzite in the Flinders Ranges of South Australia and of coeval strata in Namibia, i.e. the Kuibis and Schwarzrand subgroups of the Nama Group (Saylor et al., 1995), is missing in the shallow-water regression-induced hiatus between the Dengying Limestone and the Yangjiahe Formation in Hubei and elsewhere in South China. The apparent lack of vendobionts on the Yangtze Platform is, however, compensated by a quite diverse alternative record of Shaanxilithes, Gaojiashania, cloudinids, conotubidids, vendotaenids and trace fossils.

Next in similarity to the Yangtze Platform lithofacies development and Meishucunian SSF fauna of Yunnan may be coeval records from the Lesser Himalayas (Krol, Mussorie and Garhwal Synclines, Brasier \& Singh, 1987), from the Elburz Mountains of Iran (Brasier et al., 1990) and the Malyi Karatau Hills of Kazakhstan (Missarzhevsky \& Mambetov, 1981). The lithological sequences and biological data of these areas show a greater similarity, especially with the Yunnan facies, than with the Siberian Lena-Aldan Platform record (Yudomian-Nemakit-Daldynian-Tommotian, see Astashkin et al., 1990) or with the Anti-Atlas of Morocco, Namibia, the White Sea coast of northern European Russia, North American, Brazilian-Bolivian (Corumbá, Walde, 1987; Trompette et al., 1998) and Uruguayan successions (Arroyo del Soldado Group, Gaucher, 2000; Gaucher et al., 2003). All these sequences have been reviewed by biostratigraphic and chemostratigraphic methods and respective correlations have been attempted.

Correlations between the Precambrian-Cambrian boundary stratotype section at Fortune Head (Avalon Peninsula, eastern Newfoundland, Landing, 1994) with the Yangtze Platform because all paleo-high latitude proto-Gondwana boundary sections (such as from Appalachian eastern North America, Morocco, Spain, Wales, UK, Germany, Czech Republic, Jordan, etc.) document a very distinct clastic dominated facies which does not easily correlate with the Yangtze Platform (Landing, 1998; Landing et al., 1998 ). The very thick (more than $6 \mathrm{~km}$ !) clastic Fortune Head section has constantly yielded new deeper stratigraphic levels revealing metazoan traces and SSF, presenting a probably far more continuous record across this boundary interval than any of the other sections, but resulting in ever new updated adjustments of this boundary and cumbersome correlation problems.
The Terminal Neoproterozoic sections in the Corumbá region on both sides of the Brazilian-Bolivian border have recently been scrutinized by Trompette et al. (1998), Gaucher (2000) and in great detail by Gaucher et al. (2003), who, based upon a palynological record, correlated the Arroyo del Soldado Group of central Uruguay with the probably closely related Cerradinho and Tamengo formations of the Corumbá Group. In the Pantanal area of Mato Grosso do Sul (central-west of Brazil) the Corumbá Group is disjunctly underlain by a thick sequence of high-grade BIFs (Santa Cruz Formation) and these, in turn, by cap-dolomites of the Bocaina Formation, which, further downsection, overlay the diamictites of the Jacadigo Group and the tillites of the Puga Formation. Apparently, a complete post-glacial Vendian succession with some similarities to the Sinian sequence of the Yangtze Platform may have developed in Brazil and Uruguay, too. The iron-rhythmites of the Jacadigo Group, containing large dropstones in certain horizons, may have developed under marine peri-glacial conditions as the banded iron-silicates of the Doushantuo 2 Member near Kunyiang in the Kunyiang-Weng'an Uplift region of central Guizhou. Kirschvink et al. (1999) attributed these BIFs to cyanobacterial blooms and massive oxygen production during the earliest melting of the Proterozoic ice shields having caused conditions similar to the Paleoproterozoic BIF formation worldwide. It must be noted that the most important macrofossils described from few horizons of green mudstones of the Tamengo Formation, Cloudina riemkeae and Corumbella werneri (Hahn et al., 1982), especially the latter form, show remarkable similarities with the middle Dengying Conotubus Ding et al., 1992 and related conotubular fossil remains such as Gaojiashania from the northern margins of the Yangtze Platform (Zhang \& Hua, 2000; Hua et al., 2000a,b). The true nature and functions as well as the taxonomy of Cloudina and these conotubular fossils from upper levels of Terminal Neoproterozoic beds is not well understood as yet and requires a comprehensive study of material from all localities. According to Hahn et al. (1982), Conway Morris (1998a), and Xiao et al. (2002), it is very probable to expect an ancestral scyphozoan "affinity" for some of these first conotubular fossils. However, alternatively to a body-fossil taxonomic assignment, as established for the cone-shaped enzymatically secreted Cloudina, the ringed tubular fossils (like Corumbella and Gaojiashania) could be interpreted as excrement- or mucus-lined tubes or pipes of worm-like organisms. The ringed (stacked?) linings may consist of selectively agglutinated grains of hematite, pyrite or phosphate to stabilize the "living quarters", as the inhabitants crisscrossed nutrient-rich beds beneath, within, or even on top of microbial mats, similar to the life style portrayed for "undermat miners" by Seilacher (1999). Field observations from the quarry "Claudia" at Corumbá-Ladario, however, document only fragmented (although quite large!) specimens of Corumbella werneri, often aligned in a parallel fashion, which indicates post mortem transportation, possible current orientation and concentration on certain bedding surfaces. Virtually, all material demonstrates the occurrence of a "midline crack" (see Hahn et al., 1982, plates 1-3), which does not appear to be a primary 
morphological feature, but rather indicates collapse of these non-sediment-filled tubes and thus a rapid burial. In rare instances, three-dimensional sediment-filled tubes were observed, which then were embedded as very small fragments, however.

\section{CONCLUSIONS}

Due to pandemic and regional rifting (break-up of Rodinia) and late intracratonic contractional movements (documented by intermittent volcanic activities) the South China Plate offered a scenario of "mosaic patterns" of structural highs and lows which induced and favored developments of individual islands, platforms and basins forming multiple lithofacies and thus biofacies regions. However, the general NW-SE trend of a platform to basin gradient was maintained (see Figure 1).

The individual lithofacies developments produced "experimental" habitats for biota during the critical Ediacaran time interval. Due to the high variation in lithofacies also special taphonomical conditions existed, which permitted preservation of soft-bodied biota, but only mega-algal structures were encountered (Miaohe Floral Lagerstätten, Steiner et al., 1993) during the Ediacaran, and a rich highly diversified metazoan fauna appeared initially during the earliest Cambrian (Niutitang and Chengjiang Faunal Lagerstätten). The non appearance of Ediacara-type fossils on the South China Plate is attributed to the lack of highenergy sandy biotopes and/or climatological factors.

It is corroborated by investigations of stratigraphically controlled sections within the marginal platformal lithofacies in China that earliest attempts at biomineralization were successfully employed during late Ediacaran times by a) "fecal agglutination" as documented by "worm-like" fossils such as Gaojiashania and, in Brazil, by Corumbella, and b) by enzymatic secretion of calcitic tubes as documented by Cloudina both in China and Brazil (and elsewhere).

The first occurrences of both Corumbella-Gaojiashania and Cloudina is within a narrow time slice near the top of the Ediacaran Period. It is suggested to use these fossils as biostratigraphical indicators of zonal rank for the latest Proterozoic time-slice prior to the first appearance of SSF on a global scale. The occurrence of Corumbella-Gaojiashania and of Cloudina is strictly facies-controlled to indicate deeper subtidal, but fairly well-oxygenated epifaunal to para-infaunal life-styles. A direct dependence to biomats cannot be verified and bedding-plane penetration (growth indicates compensation with sediment accumulation!) may not have been accomplished by Cloudina as yet (Seilacher's Agronomical Revolution).

With reference to the Brazilian (Corumbá) and Uruguayan Late Ediacaran biostratigraphy the Corumbella-Cloudina Biozone represents the terminal Neoproterozoic closure of the marginal intracratonic rift basin prior to the advent of SSF and thus prior to the deposition of Lower Cambrian sediments because reported simple-design trace fossils also co-occur within the Corumbella-Cloudina Biozone elsewhere, especially within the Gondwana biofacies.

\section{ACKNOWLEDGMENTS}

The author wishes to acknowledge Dermeval A. do Carmo and Detlef Walde (UnB, Brazil) by the generous invitation of submitting this paper to this issue and the substantial advice which was received by Renata Netto (UNISINOS). Detlef Walde expertly guided me to the fossil sites around Corumbá, Mato Grosso do Sul and into the Jacadigo Hills. The field assistance of F. G.Santiago and Tomás and Rosangela Pontara of Corumbá is gratefully acknowledged. For many scientific data and information I like to thank Michael Steiner, Bernd Weber and Shixue Hu (TUB "China Geoscience Research Centre”), Christoph Heubeck (Freie Universität Berlin), Zhu Maoyan and Zhang Junming (Nanjing Institute of Geology and Palaeontology, Chinese Academy of Sciences), and Zhao Yuanlong (Guizhou University of Technology). Last - but by no means least - I wish to acknowledge the sponsorship of this research since 1990 by Deutsche Forschungsgemeinschaft (Grant No. Er 96/32-1/2 and several previous grants) and by the National Natural Science Foundation of China (Yao Yupeng, Beijing). Harald Strauss (University of Muenster) provided advice concerning key geochemical references for this manuscript.

\section{REFERENCES}

ALL-China Commitee of Stratigraphy. 2001. Stratigraphic guide of China (revised edition): regional chronostratigraphic chart of China. Beijing, Geological Publishing House, p. 159.

Alvarenga, C.J.S.; Moura, C.A.V.; Gorayeb, P.S.S. \& Abreu, F.A.M. 2000. Paraguay and Araguaia Belts. In: D.G. Cordani; E.J. Milani; T. Filhu \& D.A. Campos (eds.) Tectonic Evolution of South America, INTERNATIONAL GEOLOGICAL CONGRESS, 31, 2000. Proceedings, Rio de Janeiro, SBG, p. 183-193.

Astashkin, V.A.; Varlamov, A.I.; Esakova, N.V.; Zhuravlev, A.Yu.; Repina, L.N.; Rozanov, A.Yu.; Fedorov, A.B. \& Shabanov, Yu.Ya. 1990. Guide on Aldan and Lena Rivers, Siberian Platform. In: INTERNATIONAL SYMPOSIUM ON CAMBRIAN SYSTEM, 3, 1990. Novosibirsk, Academy of Science USSR (Siberian Branch), $115 \mathrm{p}$.

Bengtson, S. \& Yue, Z., 1992. Predatorial borings in Late Precambrian mineralized exo-skeletons. Science, 257:367-369.

Brasier, M.D. 1979. The Cambrian radiation event. In: M.R. House (ed.) The origin of major invertebrate groups, Academic Press, p. 103-159.

Brasier, M.D.; Magaritz, M.; Corfield, R.; Luo, H.; Wu, X.; Ouyang, L.; Jiang, Z.; Hambdi, B.; He, T. \& Fraser, A.G. 1990. The carbon- and oxygen-isotope record of the PrecambrianCambrian boundary interval in China and Iran and their correlation. Geological Magazine, 127(4):319-332.

Brasier, M. \& Singh, P. 1987. Microfossils and PrecambrianCambrian boundary stratigraphy at Maldeota, Lesser Himalaya. Geological Magazine, 124(4):323-345.

Conway Morris, S. 1998a. Metazoan phylogenies: falling into place or falling to pieces? A palaeontological perspective. In: W. F. Doolittle \& M. Akam (eds.) Genomes and evolution, Current Opinion in Genetics \& Development, 8:662-667. 
Conway Morris, S. 1998b. Eggs and embryos from the Cambrian. BioEssays, 20(8):676-682.

Ding, L.; Zhang, Y. \& Dong, J. 1992. The study of the Late SinianEarly Cambrian biotas from the northern margin of the Yangtze Platform. Beijing, Scientific and Technical Documents Publishing House, $135 \mathrm{p}$.

Erdtmann, B.-D. \& Steiner, M. 2001. Special observations concerning the Sinian-Cambrian transition and its stratigraphic implications on the central and SW Yangtze Platform, China. Palaeoworld, 13:52-65.

Gaucher, C. 2000. Sedimentology, palaeontology, and stratigraphy of the Arroyo del Soldado Group (Vendian to Cambrian, Uruguay). Beringeria, 26:1-120.

Gaucher, C.; Boggiani, C. P.; Sprechmann, P.; Sial, A.N. \& Fairchild, T. 2003. Integrated correlation of the Vendian to Cambrian Arroyo del Soldado and Corumbá Groups (Uruguay and Brazil): palaeogeographic, palaeoclimatic and palaeobiologic implications. Precambrian Research, 120(2003):241-278.

Hahn, G.; Hahn, R.; Leonardos, O.H.; Pflug, H.D. \& Walde, D.H.G. 1982. Körperlich erhaltene Scyphozoen-Reste aus dem Jungpräkambrium Brasiliens. Geologica et Palaeontologica, 16:1-18.

Hua, H.; Zhang, L.; Zhang Z. \& Wang J. 2000a. New fossil evidences from Latest Neoproterozoic Gaojiashan biota, South Shaanxi. Acta Palaeontologica Sinica, 39(3):381-390.

Hua, H.; Zhang, L.; Zhang, Z. \& Wang, J. 2000b. Fossil evidences of Latest Neoproterozoic Gaojiashan Biota and their characteristics. Acta Palaeontologica Sinica, 39(4):507-515.

Kirschvink, J.L.; Gaidos, E.J.; Beukes, N.J. \& Gutzmer, J. 1999. The Paleoproterozoic Snowball Earth: cyanobacterial blooms and the deposition of the Kalahari manganese field. In: GEOLOGICAL SOCIETY OF AMERICA ANNUAL MEETING, 31, 1999. Denver, CD-ROM, Abstract No. 52323.

Knoll, A. 2003. Chairman's Message: Terminal Proterozoic System. In: IUGS Subcommission on the Terminal Proterozoic System, $16^{\text {th }}$ Circular, March 2003.

Landing, E. 1994. Precambrian-Cambrian boundary global stratotype ratified and a new perspective of Cambrian time. Geology, 22:179-182.

Landing, E. 1998. Cambrian subdivisions and correlations: introduction. Canadian Journal of Earth Sciences, 35(4):321-322.

Landing, E.; Bowring, S.A.; Davidek, K.L.; Westrop, S.R.; Geyer, G. \& Heldmaier, W. 1998. Duration of the Early Cambrian: U$\mathrm{Pb}$ ages of volcanic ashes from Avalon and Gondwana. Canadian Journal of Earth Sciences, 35(4):329-338.

Mehl, D. \& Erdtmann, B.-D. 1994. Sanshaptinella dapingi n.gen., n.sp. - a new hexactinellid sponge from the Early Cambrian (Tommotian) of China. Berliner geowissenschaftliche Abhandlungen 13(E):315-319.

Mens, K. \& Pirrus, E. 1986. Stratigraphical characteristics and development of Vendian-Cambrian boundary beds on the East European Platform. Geological Magazine, 123(4):357-360.

Missarzhevsky, V.V. \& Mambetov, A.J. 1981. Stratigraphy and fauna of Cambrian and Precambrian boundary beds of Maly Karatau. Trudy Akademii Nauk SSSR, Moscow, 326:1-90 (in Russian).

Powell, C.M. 1995. Are Neoproterozoic glacial deposits preserved on the margins of Laurentia related to the fragmentation of two supercontinents? Comment. Geology 23:1053-1054.

Powell, C.M.; Li, C.X.; McElhinny, M.W.; Meert, J.G. \& Park, J.K. 1993. Paleomagnetic constraints on timing of the Neoproterozoic breakup of Rodinia and the Cambrian formation of Gondwana. Geology 21:880-892.

Saylor, B.Z.; Grotzinger, J.P. \& Germs, G.J.B. 1995. Sequence stratigraphy and sedimentology of the Neoproterozoic Kuibis and Schwarzrand Subgroups (Nama Group), southwestern Namibia. Precambrian Research, 73(1995):153-171.
Schrag, D.P.; Hoffman, P.F. \& Bowring, S.A. 1999. Geochemical and isotopic implications of the Snowball Earth hypothesis. In: GEOLOGICAL SOCIETY OF AMERICA ANNUAL MEETING, 31, Denver, CD-ROM, Abstract No. 52314.

Seilacher, A. 1999. Biomat-related lifestyles in the Precambrian. Palaios, 14:86-93.

Shields, G.; Stille, P. \& Brasier, M.D. 2000. Isotopic records across two phosphorite giant episodes compared: the Precambrian-Cambrian and the Late Cretaceous-Recent. In: C.G. Glenn, L. Prévot-Lucas \& J. Lucas (eds.) Marine authigenesis: from global to microbial, SEPM (Society for Sedimentary Geology), p. 103-115 (Special Publication $66)$.

Steiner, M.; Mehl, D.; Reitner, J. \& Erdtmann, B.-D. 1993. Oldest entirely preserved sponges and other fossils from the Lowermost Cambrian and a new facies reconstruction of the Yangtze platform (China). Berliner geowissenschaftliche Abhandlungen, 9(E):293-329.

Steiner, M.; Wallis, E.; Erdtmann, B.-D.; Zhao, Y. \& Yang, R. 2001. Submarine-hydrothermal exhalative ore layers in black shales from South China and associated fossils - insights into a Lower Cambrian facies and bio-evolution. Palaeogeography, Palaeoclimatology, Palaeoecology, 169(2001): 165-191.

Sun, W. 1986. Late Precambrian pennatulids (sea pens) from the eastern Yangtze Gorge: Paracharnia gen.nov. Precambrian Research, 31:361-375.

Trompette, R.; de Alvarenga, C.J.S. \& Walde, D. 1998. Geological evolution of the Neoproterozoic Corumbá graben system (Brazil). Depositional context of the stratified Fe and Mn ores of the Jacadigo Group. Journal of South American Earth Sciences, 11(6):587-597.

Walde, D.H.G. 1987. Estratigrafia y desarrollo del Precámbrico tardío en las immediaciones de Corumbá, Brasil. In: H. Miller (ed.) Investigaciones alemanas recientes en Latinoamérica: Geologia, Weinheim, Proyectos de la Deutsche Forschungsgemeinschaft, p. 98-107.

Weber, B. \& Zhu, M. 2003. Arthropod trace fossils from the Zhujiaqing Formation (Meishucunian, Yunnan) and their palaeobiological implications. Progress in Natural Science, 13(10):795-800

Xiao, S.; Zhang, Y. \& Knoll, A.H. 1998. Three-dimensional preservation of algae and animal embryos in a Neoproterozoic phosphorite. Nature, 391:553-558.

Xiao, S.; Yuan, X.; Steiner, M. \& Knoll, A.H. 2002. Macroscopic carbonaceous compressions in a Terminal Proterozoic shale: a systematic reassessment of the Miaohe Biota, South China. Journal of Paleontology, 76(2):347-376.

Xue, Y.; Zhou, C. \& Tang, T. 1999. “Animal embryos”, a misinterpretation of Neoproterozoic microfossils. Acta Micropalaeontologica Sinica, 16(1):1-4.

Yue, Z. \& Bengtson, S. 1999. Embryonic and post-embryonic development of the Early Cambrian cnidarian Olivooides. Lethaia, 32:181-195.

Zhang, L. \& Hua H. 2000. Late Sinian tubular shell fossils and their significance. Acta Palaeontologica Sinica, 39(3):326-333.

Zhang Y.; Yin, L.; Xiao, S. \& Knoll, A. 1998. Permineralized fossils from the Terminal Proterozoic Doushantuo Formation, South China. Journal of Paleontology, 72(Suppl. 4):1-52.

Zhao, Y.; Steiner, M.; Yang, R.; Erdtmann, B.-D.; Guo Q.; Zhou, Z. \& Wallis, E. 1999. Discovery and significance of the early metazoan biotas from the Lower Cambrian Niutitang Formation, Zunyi, Guizhou, China. Acta Paeontologica Sinica, 38(Suppl.): 132-144. 